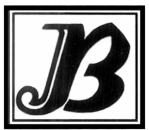

J. bio-sci. 21: 35-41, 2013

ISSN 1023-8654

http://www.banglajol.info/index.php/JBS/index

\title{
CHANGES IN CONTENTS OF SOME CHEMICAL COMPOSITIONS AND ACTIVITIES OF HYDROLYTIC AND OXIDATIVE ENZYMES OF COCCINIA CORDIFOLIA L. FRUITS
}

\author{
Ayesha Siddika, Md. Ashraduzzaman ${ }^{1}$, Shahanaz Khatun,* \\ M M H Khan, Farzana Pervin \\ Department of Biochemistry and Molecular Biology, University of Rajshahi, Rajshahi-6205, Bangladesh, \\ ${ }^{1}$ Department of Chemistry, Rajshahi University of Engineering and Technology, Rajshahi-6204, Bangladesh
}

\begin{abstract}
Context: Coccinia Cordifolia Lin. is an important tropical vegetable and it belongs to the Cucurbitaceae family. The fruits of $C$. cordifolia as a rich source of different nutrients were analyzed.

Objective: Studies were conducted to investigate the changes of nutritional compositions and hydrolytic and oxidative enzymes of $C$. cordifolia fruits at different maturity levels.

Materials and Methods: The $\mathrm{pH}$ was measured by $\mathrm{pH}$ meter. The moisture and ash contents were determined by the method of AOAC. Total and water-soluble proteins were determined by the microKjeldhal method and spectrophotometrically respectively. Lipid contents were determined by Bligh and Dyer. Total sugar and starch content were estimated by Anthrone method. Thiamin and riboflavin were estimated by Anonymous and $\beta$-carotene was estimated by Jensen. Vitamin- $C$ content was determined by the titrimetric method. Calcium, iron, sodium, potassium, cupper and magnesium content were determined by Atomic Absorption Spectroscopic method. Phosphorus was determined by colorimetric means. The protease and amylase activity were measured by Kunitz and Jayaraman respectively. Invertase activity was assayed by Mahadevan and Sridhar.

Results: The $\mathrm{pH}$ was acidic. The moisture content decreased and ash content increased with age. Protein, total sugar, reducing sugar, lipid and vitamin contents increased rapidly while starch content decreased with maturation. Mineral contents increased up to the mature stage and decreased in ripen stage. The activity of amylase and invertase increased up to mature and thereafter decreased. Polyphenol oxidase and peroxidase activity were high in immature stage but decreased in matured stage and thereafter increased in ripen stage while the activity of protease and lipase increased all the maturity stage.

Conclusion: In this study, ripen $C$. cordifolia fruits contained the highest amount of protein, total sugar, reducing sugar, $\beta$-Carotene, vitamin $B_{1}$, vitamin $B_{2}$ and vitamin $C$ whereas matured and immatured $C$. cordifolia fruits are rich sources of minerals and starch respectively.
\end{abstract}

Key words: Chemical compositions, C. cordifolia fruits, mineral, vitamin, maturation.

\section{Introduction}

Nutritional status is the great factor of the health profile of a community. Good health is directly related to better education level. According to the UNDP estimates, people of Bangladesh living under the poverty line in 2009 accounted for $40.0 \%$ (UNDP, 2009). In this country, earlier nutritional survey carried out and indicated that the principal impediment to better nutrition is the inadequate calorie intake. Reis et al (1987) reported that the density of the nutrient of cooked food is lower compared to uncooked food. Different kinds of vegetables and fruits are available in Bangladesh those are rich in nutrients but most of them are seasonal and expensive and people consumed as cooked food. Coccinia cordifolia Linn. Syn. Coccinia indica and Coccinia grandis (English-Ivy gourd) is a tropical plant of the Cucurbitaceae family. It grows well in India,

\footnotetext{
* Corresponding author E-mail: dr.khatun@yahoo.com
} 
Bangladesh, Malaysia, Indonesia and Thailand, as well as in other tropical areas. Young and tender green fruits are eaten raw in salads or cooked and added to curries. Ripe scarlet fruit is eaten raw (Gardenbed.com 2001). Different parts of this plant are used in the indigenous system of medicine for the treatment of a variety of human disease, such as diabetes, gonorrhea, cataracts, skin eruption. C. cordifolia is a good source of calcium, protein and fiber (Bharathi 2007, Simopoulos \& Gopalan 2003). It also contains beta carotene (Sachan \& Chundawat 1985). During maturation and senescence of fruits, proteolytic and hydrolytic enzymes play an important physiological role (Hashinaga et al. 1983, Desai \& Deshpande 1978). As a result of catabolic and metabolic processes, dramatic chemical and physical changes occur during ripening, which might be enzyme directed processes (Dilley 1970). Data on the physico-chemical compositions of different maturity stages of $C$. cordifolia $\mathrm{L}$. fruits grown in Bangladesh are not available. This research work is designed to obtain information on the nutritional quality of $C$. cordifolia $L$. fruits available in Bangladesh.

Therefore, in present investigation, C. cordifolia L. fruits have been selected to analyze their chemical compositions as well as the activities of some enzymes at three different maturity stages.

\section{Materials and Methods}

Coccinia cordifolia fruits were collected from Rajshahi University Campus, Bangladesh at different maturity stages for experimental purposes (Fig. 1). Days were required from the time of fruit harvesting for immature, mature and ripen stages are $8 \pm 3,15 \pm 4,25 \pm 5$ days respectively.

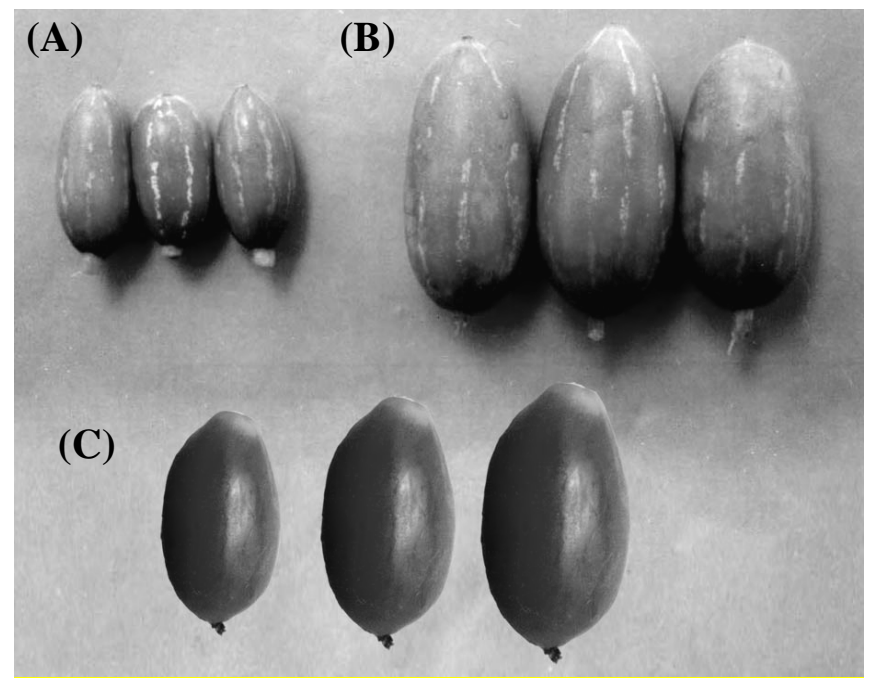

Fig. 1. Coccinia Cordifolia fruits at different maturity stages
(A) Immature stage
(B) Mature stage and
(C) Ripen stage

Freshly harvested Coccinia cordifolia fruits at different maturity levels were brought to the laboratory of Biochemistry, Rajshahi University for experimental purpose. The nutritional compositions and enzyme activities were studied by the following methods:

About $5 \mathrm{~g}$ of fruits were crushed thoroughly in a mortar with pestle and homogenized well with $10-20 \mathrm{ml}$ of distilled water and then filtered through two layers of muslin cloth. The filtrate was then clarified by centrifugation at $3000 \mathrm{~g}$ for $10 \mathrm{~min}$ and used for the experimental purposes. 
The $\mathrm{pH}$ of the filtrate was determined using $\mathrm{pH}$ meter (Corning 215). The moisture and ash contents were determined by the method of AOAC (1990). The total protein and water-soluble protein were determined by the micro-Kjeldhal method by Jayaraman (1981) and spectrophotometrically (Lowry et al., 1951) respectively. Lipid contents were determined colorimetrically as per Bligh and Dyer (1959). Total sugar content was estimated colorimetrically by Anthrone method (Dubois et al., 1951). Starch content was estimated colorimetrically by Anthrone method as described by Jayaraman (1981).

The vitamins, such as thiamin and riboflavin were estimated following the procedure as described by Anonymous (1965) while $\beta$-carotene were estimated following the method described by Jensen (1978). Vitamin-C content was determined by the titrimetric method (Bessey \& King 1933). The minerals such as calcium, iron, sodium, potassium, cupper and magnesium content were determined by Atomic Absorption Spectroscopic method of Issac and Johnson (1975). Phosphorus was determined by colorimetric means (Virmani \& Narula 1995).

For preparation of crude enzyme extract about $10 \mathrm{~g}$ of fruits were ground in a mortar with pestle and then homogenized well with cold $0.1 \mathrm{M}$ phosphate buffer of respective $\mathrm{pH}$ (amylase, $\mathrm{pH}$ 6.7, protease, $\mathrm{pH}$ 7.0, invertase, $\mathrm{pH} 7.0$,), while for the measurement of lipase $50 \mathrm{mM}$ acetate buffer, $\mathrm{pH} 5.6$ was used. After centrifugation at $8000 \mathrm{~g}, 4^{\circ} \mathrm{C}$ for $10 \mathrm{~min}$. the clear supernatant was used as crude enzyme extract. The protease activity was measured by the method of Kunitz (1947) while the activity of amylase was determined as per Jayaraman (1981). Invertase activity was assayed following the modified method as described in methods in physiological Plant Pathology (Mahadevan \& Sridhar 1982).

All data were expressed on the mean and \pm standard deviation (SD) of three experiments and were subjected to one way analysis of variance (ANOVA). The mean values were compared at $P<0.05$ significance level by Duncan's multiple range tests using SPSS 11.5 software package.

\section{Results and Discussion}

Table1 shows the $\mathrm{pH}$, moisture and ash contents of $C$. cordifolia fruits at different maturity stages. The $\mathrm{pH}$ of C. cordifolia fruits is in acidic ranges at all the maturity stages. The moisture contents of $C$. cordifolia fruits were found $91.98 \%, 89.88 \%$ and $87.14 \%$ in mature, immature and ripen stages respectively. The results also revealed that the moisture of $C$. cordifolia fruits decreased gradually, while ash content increased in the fruits with the advancement of maturity. The decreased in moisture content with the advancement of maturity might be due to accumulation of solid materials.

Table 2 shows the total protein, water soluble protein and total lipid content of fruits at different maturity levels. The total protein content of $C$. cordifolia fruits were found $2.58 \%$ in immature, $7.37 \%$ in mature and $11.29 \%$ in ripen stages. Present study also indicated that like total protein, the amount of the water soluble protein is also increased significantly in all maturity stages but the total protein content determined by MicroKjeldhal method showed considerably higher value than water soluble protein by the Lowry method. Bhatnagar and Tewari (1971) reported that $C$. cordifolia fruits are rich sources of protein which is similar to this study. In this study, in ripen stage $(11.29 \%)$, C. cordifolia fruits contain highest amount of protein than immature and mature stage. $C$. cordifolia fruits contents low amount of lipid. It may be concluded from the result that the lipid content increased with the advancement of maturity but the difference is not significant $(P$ $<0.05)$. 
Table 1. $\mathrm{pH}$, Moisture and ash contents of $C$. cordifolia fruits at different maturity levels (on the basis of fresh weight).

\begin{tabular}{cccc}
\hline \multirow{2}{*}{ Parameters } & \multicolumn{3}{c}{ Stages of Maturation } \\
\cline { 2 - 4 } & Immature & Mature & Ripen \\
\hline pH & $6.20 \pm 0.04^{\mathrm{c}}$ & $5.40 \pm 0.01^{\mathrm{b}}$ & $4.10 \pm 0.02^{\mathrm{a}}$ \\
Moisture (gm \%) & $91.98 \pm 0.2^{\mathrm{c}}$ & $89.88 \pm 0.34^{\mathrm{b}}$ & $87.14 \pm 0.02^{\mathrm{a}}$ \\
Ash (gm \%) & $1.00 \pm 0.03^{\mathrm{a}}$ & $1.68 \pm 0.04^{\mathrm{b}}$ & $2.12 \pm 0.01^{\mathrm{c}}$ \\
\hline
\end{tabular}

Values are mean \pm S.D. of triplicate analyses. Mean in the same row with different superscripts are significantly $(P<0.05)$ different.

Table 2. Total protein, water soluble protein and total lipid content of $C$. cordifolia fruits at different maturity levels (on the basis of fresh weight).

\begin{tabular}{cccc}
\hline Parameters & \multicolumn{3}{c}{ Stages of Maturation } \\
\cline { 2 - 4 } & Immature & Mature & Ripen \\
\hline Total protein (gm \%) & $2.58 \pm 0.001^{\mathrm{a}}$ & $7.37 \pm 0.003^{\mathrm{b}}$ & $11.29 \pm 0.002^{\mathrm{c}}$ \\
Water soluble protein (gm \%) & $1.06 \pm 0.006^{\mathrm{a}}$ & $2.55 \pm 0.001^{\mathrm{b}}$ & $4.32 \pm 0.001^{\mathrm{c}}$ \\
Total lipid (gm \%) & $0.20 \pm 0.004^{\mathrm{a}}$ & $0.22 \pm 0.005^{\mathrm{a}}$ & $0.25 \pm 0.002^{\mathrm{a}}$ \\
\hline
\end{tabular}

Values are mean \pm S.D. of triplicate analyses. Mean in the same row with different superscripts are significantly $(P<0.05)$ different.

Table 3. Total sugar, reducing sugar and starch contents of $C$. cordifolia fruits at different maturity levels. (on the basis of fresh weight).

\begin{tabular}{cccc}
\hline & \multicolumn{3}{c}{ Stages of Maturation } \\
\cline { 2 - 4 } Parameters & Immature & Mature & Ripen \\
\hline Total sugar (gm \%) & $0.89 \pm 0.003 \mathrm{a}$ & $1.55 \pm 0.001 \mathrm{~b}$ & $6.50 \pm 0.005 \mathrm{c}$ \\
Reducing sugar (gm \%) & $0.39 \pm 0.003 \mathrm{a}$ & $0.52 \pm 0.004 \mathrm{~b}$ & $2.06 \pm 0.003 \mathrm{c}$ \\
Starch (gm \%) & $5.55 \pm 0.002 \mathrm{c}$ & $3.09 \pm 0.007 \mathrm{~b}$ & $1.88 \pm 0.001 \mathrm{a}$
\end{tabular}

Values are mean \pm S.D. of triplicate analyses. Mean in the same row with different superscripts are significantly $(P<0.05)$ different.

Total sugar, reducing sugar and starch contents of $C$. cordifolia fruit were shown in Table 3 . The result indicated that the total sugar content of $C$. cordifolia fruits increased significantly with the change of maturity. These results were similar to the finding of Abdullah et al. (1985) who reported that total sugar content of banana increased with the change of maturity. The reducing sugar contents of $C$. cordifolia fruits also increased significantly with the change of maturity, while the starch content of the fruit decreased significantly with maturation. The total sugar and reducing sugar contents were found to vary between $0.89-6.50 \%$ and 0.39- 2.06\% respectively. The starch contents of $C$. cordifolia fruits was found to vary from 1.88 to $5.55 \%$ respectively. The reduction of starch with the change of maturity might be due to the hydrolysis of starch, which shows good correlation with the increase in the contents of total soluble sugar. 
Table 4. Vitamins and minerals content of $C$. cordifolia fruits at different maturity levels (on the basis of fresh weight).

\begin{tabular}{cccc}
\hline Parameters & \multicolumn{3}{c}{ Stages of Maturation } \\
\cline { 2 - 4 } & Immature & Mature & Ripen \\
\hline Vitamin $B_{1}(m g \%)$ & $0.50 \pm 0.12^{\mathrm{a}}$ & $0.60 \pm 0.32^{\mathrm{b}}$ & $0.63 \pm 0.23^{\mathrm{c}}$ \\
Vitamin $\mathrm{B}_{2}(\mathrm{mg} \%)$ & $0.21 \pm 0.04^{\mathrm{a}}$ & $0.25 \pm 0.05^{\mathrm{b}}$ & $0.29 \pm 0.05^{\mathrm{c}}$ \\
B-Carotene $(\mu \mathrm{g} \%)$ & $3405 \pm 0.24^{\mathrm{a}}$ & $3900 \pm 0.12^{\mathrm{b}}$ & $4123 \pm 0.14^{\mathrm{c}}$ \\
Vitamin-C $(\mathrm{mg} \%)$ & $12.00 \pm 0.001^{\mathrm{a}}$ & $13.50 \pm 0.002^{\mathrm{b}}$ & $14.00 \pm 0.005^{\mathrm{c}}$ \\
Potassium $(\mathrm{mg} \%)$ & $137.40 \pm 0.03^{\mathrm{a}}$ & $148.40 \pm 0.04^{\mathrm{b}}$ & $137.00 \pm 0.05^{\mathrm{a}}$ \\
Calcium $(\mathrm{mg} \%)$ & $48.84 \pm 0.05^{\mathrm{a}}$ & $56.35 \pm 0.14^{\mathrm{c}}$ & $50.80 \pm 0.24^{\mathrm{b}}$ \\
Sodium $(\mathrm{mg} \%)$ & $0.72 \pm 0.40^{\mathrm{a}}$ & $0.95 \pm 0.05^{\mathrm{b}}$ & $0.72 \pm 0.03^{\mathrm{a}}$ \\
Phosphorus $(\mathrm{mg} \%)$ & $10.11 \pm 0.52^{\mathrm{a}}$ & $12.02 \pm 0.15^{\mathrm{b}}$ & $10.00 \pm 0.03^{\mathrm{a}}$ \\
Iron $(\mathrm{mg} \%)$ & $1.00 \pm 0.23^{\mathrm{a}}$ & $1.99 \pm 0.13^{\mathrm{b}}$ & $1.10 \pm 0.15^{\mathrm{a}}$ \\
Cupper $(\mathrm{mg} \%)$ & $46.00 \pm 0.55^{\mathrm{a}}$ & $56.0 \pm 0.34^{\mathrm{b}}$ & $46.00 \pm 0.24^{\mathrm{a}}$ \\
Magnesium $(\mathrm{mg} \%)$ & $69.20 \pm 0.03^{\mathrm{a}}$ & $79.45 \pm 0.05^{\mathrm{c}}$ & $69.00 \pm 0.04^{\mathrm{a}}$ \\
\hline
\end{tabular}

Values are mean \pm S.D. of triplicate analyses. Mean in the same row with different superscripts are significantly $(P<0.05)$ different.

The vitamins and minerals content were shown in Table 4. It was found that $C$. cordifolia fruits are good sources of vitamins. Vitamin $B_{1}(0.50-0.63 \mathrm{mg} \%)$, Vitamin $B_{2}(0.21-0.29 \mathrm{mg} \%)$, B-Carotene (3405-4123 $\mu \mathrm{g}$ $\%)$ and vitamin C (12.00-14.00 $\mathrm{mg} \%)$ contents increased with the advancement of maturity but the change was not significant $(\mathrm{p}<0.05)$. The major minerals analyzed in $C$. cordifolia fruits are potassium $(137.00-148.40$ $\mathrm{mg} \%$ ), calcium (48.84-56.35 mg \%), sodium (0.72-0.95 mg \%), phosphorus (10.00-12.02 mg \%), iron (1.00$1.99 \mathrm{mg} \%$ ), copper (46.00-56.00 mg \%) and magnesium (69.00-79.45 mg \%). All minerals content significantly increased up to the mature stage and then decreased in ripen stage.

Table 5. Activities of amylase, protease, invertase, lipase, polyphenol oxidase and peroxidase enzymes of $C$. cordifolia fruits at different maturity levels (On the basis of fresh weight).

\begin{tabular}{cccc}
\hline Name of the enzymes & \multicolumn{3}{c}{ Stages of maturation } \\
\cline { 2 - 4 } & Immature & Mature & Ripen \\
\hline Amylase (unit gm ${ }^{-1}$ fruit). & $16.55 \pm 0.01^{\mathrm{b}}$ & $22.25 \pm 0.08^{\mathrm{c}}$ & $14.15 \pm 0.01^{\mathrm{a}}$ \\
Protease (unit gm ${ }^{-1}$ fruit). & $1.55 \pm 0.03^{\mathrm{a}}$ & $4.05 \pm 0.06^{\mathrm{b}}$ & $8.35 \pm 0.02^{\mathrm{c}}$ \\
Invertase (unit gm ${ }^{-1}$ fruit). & $1.89 \pm 0.04^{\mathrm{a}}$ & $4.77 \pm 0.02^{\mathrm{b}}$ & $1.14 \pm 0.05^{\mathrm{a}}$ \\
Lipase (unit gm ${ }^{-1}$ fruit) & $10.20 \pm 0.06^{\mathrm{a}}$ & $26.30 \pm 0.08^{\mathrm{b}}$ & $33.10 \pm 0.01^{\mathrm{c}}$ \\
Polyphenol oxidase (unit min ${ }^{-1} \mathrm{gm}^{-1}$ & $34.80 \pm 0.09^{\mathrm{c}}$ & $14.10 \pm 0.01^{\mathrm{a}}$ & $29.40 \pm 0.05^{\mathrm{b}}$ \\
fruit) & & & \\
Peroxidase (unit min-1 $\mathrm{gm}^{-1}$ fruit) & $66.10 \pm 0.02^{\mathrm{c}}$ & $38.40 \pm 0.15^{\mathrm{a}}$ & $44.30 \pm 0.09^{\mathrm{b}}$ \\
\hline
\end{tabular}

Values are mean \pm S.D. of triplicate analyses. Mean in the same row with different superscripts are significantly $(P<0.05)$ different. 
Activities of some hydrolytic and oxidative enzymes in C. cordifolia fruits were shown in Table 5. The activities of amylase, protease invertase and lipase in different maturity stages of $C$. cordifolia fruits were found between 14.15 to $22.25 \mathrm{mg} \%, 1.55$ to $8.35 \mathrm{mg} \%, 1.14$ to $2.77 \mathrm{mg} \%$ and 10.20 to $33.10 \mathrm{mg} \%$ respectively. Activities of amylase and invertase increase significantly up to mature stage and thereafter decreased significantly, while the activity of protease and lipase increased with the advancement of maturity (Table 5). Among the hydrolytic enzymes, lipase shows the highest activity at ripen stages. Polyphenol oxidase and peroxidase activity increased greatly in immature stage and then decreased dramatically in mature stage and thereafter increased in ripen stage.

\section{Conclusion}

In conclusion, ripen $C$. cordifolia fruits might be considered as nutritionally rich source since it contained the highest amount of protein, total sugar, reducing sugar, $\beta$-Carotene, vitamin $B_{1}$, vitamin $B_{2}$ and vitamin $C$ whereas mature and immature $C$. cordifolia fruits are rich sources of minerals and starch respectively.

\section{Acknowledgement}

The authors are grateful to the Chairman of the Department of Biochemistry and Molecular Biology, Rajshahi University, Rajshahi-6205, Bangladesh to give the lab facility to complete this research work.

\section{References}

Abdullah HMA, Rohaya MA, Zaipun MZ. 1985. Physico-Chemical changes during maturation and after ripening of bananas (Musa sapientum cv. Embun). MARDI Research Bulletin 13(3), 341-347.

Anonymous 1965. The pharmacopoeia of the United States of America. (The United States pharmacopoeia.). Seventeenth revision, pp. 886-888. By authority of the United States of pharmacopoeial convention meeting at Washington DC.

AOAC 1990. Official methods of analysis, 15 Th Edn. Association of Official Analytical Chemists, Washington, D.C., USA.

Bessey OA, King CG. 1933. The distribution of vitamin-C in plant and animal tissues and its determination. J Biol Chem $103,687$.

Bharathi LK. 2007. Underutilized and underexploited horticultural crops (ed. by Peter KV). New Delhi: New India Publishing Agency, pp. 275-282.

Bligh EG, Dyer WJ. 1959. Total lipid extraction and purification. Can J Biochem Physiol 37, 911. http://dx.doi.org/10.1139/059-099

Desai BB, Deshpande PB. 1978. Effects of stage of Maturity on some physical and biochemical constituent enzyme activities of Banana. Mysore J Agric Sci 12, 193-201.

Dilley DR. (1970). Enzymes. Cited from the Biochemistry of Fruits and their products (Ed. A. C. Hulme), academic press, London and New York, 1, 179-207.

Dubois M, Gilles K, Robers P, Smith F. 1951. A Colorimetric method for the determination of sugars. Nature 168, 167.

http://dx.doi.org/10.1038/168167a0

Gardenbed.com. 2001. Coccinia grandis. Plants for a future. http://gardenbed.com/source/18/1800-med.asp (accessed: October 30, 2001).

Hashinaga F, Yamato F, Itoo S. 1983. Partial purification and characterization of protease from passion fruit juice. Mem Fac Agr Kagoshima Univ 19, 73-79.

Issac RA, Johnson WC. 1975. Collaborative study of wet and dry techniques for the elementary analysis of plant tissue by atomic absorption spectrophotometer. J AOAC, 58, 436. 
Jayaraman J. 1981. Laboratory Manual in Biochemistry (1st ed.) Wiley Eastern Ltd., New Delhi, India.

Jensen A. (1978). Chlorophylls and Carotenoids. In: J.A. Hellebust and J. S. Caraigie (eds.), Handbook of Phycological Methods, Cambridge Univ. Press, London, pp. 59-70.

Kunitz M. (1947). Crystalline soybean trypsin inhibitor. J. gen. Physiol. 30, 291-310. http://dx.doi.org/10.1085/jgp.30.4.291

Lowry OH, Rosebrough NJ, Farr AL, Randal RJ. 1951. Protein measurement with the Folin-Ciocalteu's reagent. J Biol Chem 193, 265-275.

Mahadeven A, Sridhar R. 1982. Physiological Plant Pathology (2nd ed.) Sivakasi Publication, Madras, India.

Reis CP, Kline K, Weaver SO. 1987. Impact of commercial eating on nutrient adequacy. J Am Diet Assoc 87, 463-468.

Sachan SCP, Chundawat BS. 1985. Ivy gourd: A prospective vegetable of south India. Indian Horticulture 29(4), 18.

Simopoulos AP, Gopalan C. 2003. Plants in human health and nutrition policy. World Rev Nutr Diet Basel Karger, 91, 60-66.

UNDP. 2009. Human and income poverty: developing countries (Population living below national poverty line) http://hdrstats.undp.org/en/indicators/104.html

Virmani OP, Narula AK. 1995. Applied Chemistry-Theory and Practice. New International Publishers, London. 